\title{
THE POLITICS OF DREAMING - FROM DIDEROT TO KEATS AND SHELLEY
}

Dreaming, seemingly a private activity, can exhibit political and ideological dimensions. The first part of this article looks at the ideological significance, within late Enlightenment and Romantic-era culture, of the very activity of dreaming, with particular reference to Diderot's Le Rêve de d'Alembert. Nocturnal dreaming and the somnambulistic behaviors closely associated with dreaming can and did challenge orthodox notions of the integral subject, of volition, of an immaterial soul, and even of the distinction between humans and animals. The second half of the article looks at two literary dreams, from the poetry of Shelley and Keats, considering how represented dreams can have pronounced ideological and political valences. The article as a whole illustrates the claims and methods of cognitive historicist literary critique.

KEYWORDS Poetry, dreams, neurology, John Keats, P. B. Shelley.

'In Dreams Begin Responsibilities', Delmore Schwartz's oblique and compact coming of age narrative, remains one of the most compelling American short stories of the last century. Its coolly seductive hold on the reader begins with its title, which Schwartz borrowed from an epigraph to W. B. Yeats's poetic volume Responsibilities, 'in dreams begins responsibility', attributed by Yeats in turn to an 'Old Play' (98). Whatever the title's ultimate provenance, its juxtaposition of dream and responsibility instantly sets us pondering: how could dreams, involuntary, cryptic and unpredictable, generate anything like duties and obligations?

The juxtaposition of politics and dreaming in this essay's title seeks to provoke a similar unsettling of categories and rethinking of conceptual boundaries. What could dreaming, perhaps our most private activity, have to do with politics, a set of inherently social practices? What might the political implications be of dreams themselves, with their strange transformations, their rambling story lines, their seemingly random jumps from one image or event to the next? In what follows, I will explore the politics of dreaming in two different but related ways. First, I will consider the ideological significance of the very activity of dreaming, as it was newly understood and represented in late enlightenment and early Romantic culture. I will then consider the political and ideological valence 
of the specific dreams represented in two important Romantic poems, P. B. Shelley's Alastor and John Keats' 'The Eve of St. Agnes'. In both parts of this essay, my reinterpretation of earlier discourses and texts has been partly inspired by my awareness of key developments in the cognitive neuroscience of dreaming. As such, the analyses that follow may be considered examples of what has been termed 'cognitive historicism' (Spolsky; Richardson, Neural Sublime 1-16).

Developments in the experimental study of sleep and dreaming, for example, first prompted scholars to look with serious interest at Romantic-era understandings of dreaming that could be seen to 'anticipate' not Freud's 'dream work' but a distinctively post-Freudian, neuroscientific account of dream formation (Lavie and Hobson). Moreover, the differences as well as the resonances between Romantic-era and neuroscientific understandings can prove instructive. For instance, the cognitive neuroscience of dreaming shows relatively little interest in what scientists now term the 'parasomnias', such as sleepwalking or talking during sleep; the preeminent dream researcher J. Allan Hobson devotes only three of the 153 pages of his highly useful Dreaming: A Very Short Introduction to the topic (82-84). For Hobson, as for most of his colleagues today, REM (rapid eye movement) dreaming garners most attention and serves as the paradigmatic example; parasomniac activities belong to non-REM (NREM) sleep, as do sleep onset dreams and the thought-like dreaming that occurs in 'slow wave' sleep (8). To the contrary, influential Romantic (and late Enlightenment) accounts of dreaming show a pronounced interest in somnambulism and similar behaviors, and view them as continuous with the vivid, hallucinatory dreaming now connected with REM sleep. Indeed, this connection helped give certain Romantic-era theories and representations of dreams their radical ideological valence.

\section{Dreaming, Somnambulism and the Corporeal Mind}

We might start with a glance at John William Polidori's 1815 medical thesis on 'Oneirodynia', his term for somnambulism and other parasomnias, as presented in an important recent article by Anne Stiles, Stanley Finger and John Bulevich. Polidori's thesis, composed in Latin, long remained nearly invisible to Romantic scholarship, although Polidori himself was well known: as Lord Byron's friend and physician, as a participant in the famed ghost story contest that generated both Mary Shelley's Frankenstein and Byron's fragmentary vampire tale, and as the author of The Vampyre (1819), the first widely popular vampire story in English. As Stiles and her co-authors explain, sleepwalking and other parasomnias suggested how the 'human body and brain could function mechanically', independent of a guiding soul or of conscious volition (790). If so, might the soul and will themselves prove epiphenomenal or altogether fictive? Small wonder that sleepwalking and related unconscious behaviors became closely associated with the vampire, that notoriously soulless and deeply unsettling figure.

Simply noting how the mind remained active during sleep could prove 'controversial' during the Romantic era, implicitly challenging as it did both ratio- 
nalist and religious notions of a unitary subjectivity guided by conscious volition (790). But Polidori's interest in 'oneirodynia' went much further. Not only did dreaming suggest a mind (or brain) that stayed active in the absence of consciousness, but this unconsciously active mind could also engage in a number of seemingly guided actions with no rational subject awake to guide them. Polidori's broad definition of somnambulism includes 'not only someone who walks while in a dream, but also someone who appears to wake up while still asleep, and who performs actions or speaks as if he were awake' (Polidori 776). He describes sleepers who 'respond to friends' questions and discourse ably', who dress themselves and 'guzzle' wine, who (endowed with 'vivid imagination') compose poems or essays or even edit them (776-777). We are not far here from 'Kubla Khan' and its famous headnote, which S. T. Coleridge would first publish the year after Polidori completed his medical thesis (Richardson, 'Coleridge').

Polidori borrowed the anecdote of a priest correcting sermons in his sleep from the Encyclopédie, which included an article entitled 'SOMNAMBULE, \& SOMNAMBULISME' by the French physician Jean-Joseph Ménuret de Chambaud. The Encyclopédie also proffers a generous definition of somnambulism, embracing the same range of activities covered by Polidori, who apparently modeled his definition on that of Ménuret de Chambaud. The latter places special emphasis on the seeming directedness and rationality that these unconscious behaviors can manifest, 'quelquefois même avec plus d'intelligence $\&$ d'exactitude' ['at times with even more intelligence and precision', my translation] than ordinarily (vol. 15: 340). Given the leading role in the Encyclopédie project taken by Denis Diderot and Jean-Baptiste le Rond d'Alembert, it comes as no surprise that Diderot's great fictional account of an elaborate dream attributed to d'Alembert, Le Rêve de d'Alembert [D'Alembert's Dream], should feature a comparably broad range of parasomniac activities, some of which exhibit an unexpectedly high degree of rational sense.

Not that coherent, connected thought and the sort of non-sense we normally associate with dreaming can be differentiated too readily or too definitively in this series of dialogues. Initially Mlle. de L'Espinasse, d'Alembert's housemate though not his bedmate, has called in Dr. Bordeu precisely because d'Alembert seems to be raving in his uncharacteristically troubled sleep: he thrashes about, throws off the covers, and talks like a 'crazy person' (113) ['tout l'air du délire' (359)] . ${ }^{1}$ Bordeu, however, who shares some of d'Alembert's crazier ideas, can turn his 'nonsense of vibrating strings and sensitive fibers' (113) ['galimatias de cordes vibrantes et de fibres sensibles' (359)] into a penetrating and corrosive discourse on the mind's instantiation in the body and its nervous system, the necessary illusion of the self, the secret workings of sensibility and more. Later in the dialogue, d'Alembert resumes talking, sometimes in his sleep and sometimes awake - the line between sleeping and waking, unconscious cognition and conscious thought, never entirely clear. In addition, during his earlier period of somniloquy (which Mlle. de L'Espinasse has providentially taken down), d'Alembert at times addresses his present friend and at times an absent and purely hallucinated interlocutor, the 'Philosophe', that is, Diderot himself, who features in a waking dia- 
logue that precedes the Rêve proper (120). Although d'Alembert never walks in his sleep, he does exhibit several of the parasomnias, including one only delineated quite recently though apparently well known to Diderot: 'sexsomnia' or 'sleep sex' (Andersen et al.). D'Alembert masturbates in his sleep, achieving orgasm, after hopefully asking his lovely companion to approach more nearly. If we can even fondle ourselves while attempting to seduce our beloved in our sleep, what can't we do without the benefit of conscious awareness?

The striking overlaps between Le Rêve de d'Alembert and Polidori's medical thesis (not to mention Coleridge's dream-generated, sexually charged 'Kubla Khan') cannot be attributed to something called 'influence', especially because, though composed in 1769, Diderot's text remained unpublished until 1830. Rather, key concerns impelling these dream writings - with the brain's activity during sleep, with unconscious mental and bodily behaviors, with the fragility of a unified self and the potential for connected discourse in the absence of conscious volition - all attest to the powerful contemporary appeal of what I have termed the 'corporeal psychologies' of the Romantic era (Richardson, British Romanticism 1-38). In France, the main expositor of a corporeal approach to mind and mental behaviors was the French Revolutionary physiologist and physician Pierre-JeanGeorges Cabanis. Cabanis drew inspiration for his corporeal approach to mind both from the philosophes generally and from the Montpellier School of Medicine in particular, not least the medical practitioner and theorist Théophile Bordeu (Moravia 52-60; Williams 32-41, 85-90) - the same Dr. Bordeu that Diderot fictionalizes in Le Rêve de d'Alembert.

Simply the fact of dreaming holds, as we have seen, potentially subversive implications for any philosophical or religious orthodoxy presupposing an integral, self-determined subject. More than this, the form that dreaming takes in 'somnambulistic' texts further provokes skepticism toward reigning orthodoxies, in underscoring how an unconscious yet active brain-mind can direct quite complex behaviors, including everything from dressing and walking out of the house to coherent conversation to poetic composition, without any waking supervision or conscious volition. Furthermore, in Le Rêve de d'Alembert, the content of d'Alembert's dream monologues, along with the dialogues that surround them, make the radical implications of dreaming explicit. The dreaming intellectual's 'nonsense' about vibrations and fibers broaches a materialist theory of mind that jettisons the soul, dissolves the unity of the self, exposes conscious volition as an illusion, instantiates cognition and character in the brain and nervous system, and erodes any firm line between humans and other animals. In short, Le Rêve de d'Alembert ushers in a number of the most important and most radical postulates of the Romantic-era corporeal psychologies soon to come.

In and of itself, dreaming challenged orthodox conceptions of a unitary self, since dreams (and the parasomniac activities closely associated with them) implied an agency independent of and even foreign to conscious subjectivity. But d'Alembert's dream goes further, incorporating an explicit critique of the integral subject in the manifest content of the dream (shaped to some extent by the waking dialogue between d'Alembert and Diderot that immediately precedes it in 
the text). D'Alembert, seconded by Bordeu and Mlle. de L'Espinasse, advances a series of analogies that suggest that the self is in fact an aggregate, held together provisionally, subject to change over time and continuous with biological processes that antedate the singular human subject. As Andrew Curran puts it in an essay on 'Monsters and the Self' in the Rêve, Diderot exposes the self or moi as a 'spurious abstraction temporarily attached to dynamic processes that extend beyond the confines of a given lifetime' (59). Diderot owes the most striking (and most famous) of these analogies, the human organism as a 'swarm of bees' (115) ['essaim d'abeilles' (361)], to the historical Bordeu himself, who had advanced the same metaphor in his 1767 treatise Recherches sur le tissue muqueax (Williams 37). Huddled together on a branch, a colony of bees seems to act as a single, unified organism, moving together and reacting together, and yet the 'cluster' ['grappe'] is in fact composed of multiple agents. Fuse the bees together, d'Alembert tells Mlle. de L'Espinasse in his dream, and the cluster becomes, in the eyes of a given perceiver, a single individual, and yet the multiplicity remains. Each human individual can be understood as just such a cluster, not of bees but of 'organs' ['organes'], which at bottom are 'only distinct animals held together by the law of continuity in a general bond of sympathy, unity, or identity' (117) ['Ne sont que des animaux distincts que la loi de continuité tient dans une sympathie, une unité, une identité générale' (362)].

If the seeming individual can better be seen as a hive of bees or, in another striking analogy, a colony of 'polyps' (119) ['polypes' (363)], then what becomes of personal volition? Predictably, it vanishes, yielding instead to a vision of multiple agents with diverse needs and conflicting wills. "While there is only one center of consciousness in an animal', Bordeu explains, there are 'many different impulses. Each organ has impulses peculiar to itself' (151) ['S'il n'y a qu'une conscience dans l'animal, il y a une infinité de volontés; chaque organe a la sienne' (387)]. So the stomach, for example, may desire food while the palate does not. What we experience as conscious volition in fact reflects the outcome of a contest among contending impulses that largely fly under the radar of consciousness. Bordeu goes on to expose 'free will' ['volunté'] as an illusion, a given volitional act reflecting merely the 'most recent impulse of desire and aversion' ['la dernière impulsion du désir et de l'aversion'], or at least the most recent one to register in conscious awareness, since we perform countless acts in an 'involuntary' ['sans vouloir'] manner (166-7/397). Even when awake, that is, we often act somnambulistically.

Notice that in some of these exchanges Diderot moves between the 'animal' and the human seamlessly. This reflects yet another radical and, at the time, highly unorthodox move: the implicit denial of any definitive boundary between human beings and other animals. The opening (waking) dialogue between Diderot and d'Alembert, in fact, has made this denial explicit: 'there is no difference between you and the animals except in degree of organization' (106) ['qu'entre l'animal et vous, il n'y a de différence que dans l'organisation' (353)] - in degree and, therefore, not in kind. It follows that there is no uniquely human soul; what makes us human consists in a more highly organized 'sensibility' ['sensibilité'], shared with other life forms and potential even in inorganic matter (95-6/345). 
In human beings, as in other animals, organization (as its root word, organ, implies) must ultimately be understood in purely bodily, corporeal terms. The material organization of the nervous system and brain (of the 'fibers' and their neural 'center') subtends cognition, character, emotion, behavior - everything. After a snatch of dialogue recounting instances of profound changes in intelligence, personality and behavior following head injuries and other assorted neural insults, Bordeu summarizes: 'If you disturb the center of the bundle of fibers [the brain], you change the whole creature whose entire being seems to be concentrated there' (153) ['Dérangez l'origine du faisceau, vou changez l'animal' (388-9)]. Toward the end of the dialogue, Mlle. de L'Espinasse offers her own summary, noting that 'memory, judgment, desires, aversions, passions, will, power, self-awareness' ['la mémoire, le jugement, lés désirs, les aversions, les passions, la volunté, la conscience du soi'] all depend on the precise 'structure of the brain' (169) ['l'organisation du cerveau' (400)]. These statements exemplify corporeal psychology at its most subversive and unorthodox: small wonder that the dialogue remained unpublished until well after Diderot's death.

Summing up recent advances in the cognitive neuroscience of dreaming, Hobson describes its 'most radical assertion' in this way: 'our so-called minds are functional states of our brains'. That is, the mind is 'not something else': not a 'spirit', not an autonomous 'entity' of any sort. Simply, mind 'is the self-activated brain' (58). As we have seen, the late Enlightenment-to-Romantic science of dreaming and 'somnambulism' arrived at much the same conclusion two centuries ago. Diderot, in fact, advances his own analogy for how the altered functional state of the brain significantly changes our experience of mind and self in dreaming. Because the brain remains active in sleep while the center of consciousness, where the network of fibers converges, has become temporarily weakened, the 'master is thrown on the mercy of his vassals or, one might say, is abandoned to the energy of his own uninhibited activity' (164) ['Le maître est abandonné à la discrétion de ses vassaux, et à l'énergie effrénée de sa propre activité' (396)]. The whole neural 'network', according to Diderot's fictionalized Bordeu, 'relaxes', and each individual fiber (the 'threads' responsible for neural transmission) 'moves, vibrates, and so transmits to the center a whole series of sensations', self-generated from memories, associations, and dimly perceived external prompts (164) ['tout le réseau se relâche et ... chaque filet du réseau s'agite, se meut, transmet a l'origine commune une foule de sensations' (396)]. Trains of association proliferate, as each neural vibration can activate, on analogy with the harmonic vibrations of a clavichord, other fibers that have become connected with it through experience or innate predisposition (170-1/400). An example within the text concerns d'Alembert's episode of what would now be termed sexsomnia: the vibrations ascending from one of his 'voluptuary fibers' (165) ['le brin voluptueaux' (396)], uninhibited by central control, trigger the alluring image of Mlle. de L'Espinasse, who is thus both hallucinated and really present at the same time.

The simultaneous loosening and incitement of association networks becomes a key aspect of the Romantic dream theories soon to come. William Hazlitt, in his essay 'On Dreams', writes that in dreaming, the 'bundles of thought' formed 
by association 'are, as it were, untied, loosened from a common center, and drift along the stream of fancy as it happens' (vol. 12: 20). Coleridge famously remarks on the 'streamy Nature of Association' in dreams, 'streamy' evoking both the heightened flow ('Fancy and Sleep stream on') and the meandering pathways of dream association (Coleridge, vol. 1: 1770, vol. 2: 2542). Coleridge draws in part on David Hartley, an 18th-century associationist philosopher important to a number of Romantic writers, who noted the 'great wildness and inconsistency' of dreams and attributed this to a recuperative disruption or 'breaking' of 'accidental association' (vol. 1: 385, 389). Hobson highlights this passage in Hartley as an early recognition of the 'hyperassociative' character of REM dreams (27). Recent neuroscience understands dream hyperassociation rather differently, however: less as the creative destruction of 'accidental' and potentially misleading associations than as the formation of loose associations and integration of new information into existing association networks (what Hartley calls 'trains of ideas' [vol. 1: 385]). According to Hobson, writing with co-researchers Robert Stickgold, Laurie Scott and Cynthia Rittenhouse, REM dreaming enhances the formation of 'weak' associations (such as thief / wrong) but not 'strong' associations (such as right / wrong), facilitating the connection of ideas, images, and remembered events that waking consciousness might never group together. Stickgold, Scott, Rittenhouse and Hobson conclude that 'this alteration in normal cognitive processing provides part of the explanation for the bizarre and hyperassociative nature of REM-sleep dreaming' (188), its 'wildness', as Hartley puts it. The work of another group of dream researchers suggests that, in enhancing the 'formation of association networks and the integration of [previously] unassociated information', REM dreaming also facilitates the sort of creativity seen in problem solving - or, one might add, in famously associative poems like 'Kubla Khan' (Cai et al. 10130). Finally, it is worth noting that Hartley too attributes the bizarre inconsistency of dreams to changes in functional brain states: 'for the brain, during sleep, is in a state so different from that in which the usual associations were formed, that they can by no means take place during vigilance' (vol. 1: 385).

\section{Dreams, the Default Mode and the Poetical (Political) Imagination}

Brain-based, corporeal approaches to dreaming - in Diderot's time as in our own - may strike some as reductive, especially in relation to the content of dreams. The tradition of mining dreams for revelatory, richly symbolic material goes back at least to the Old Testament and found its great modern expositor in Sigmund Freud, a tradition that Hobson still feels required to combat on occasion (1517, 134). Empirical research on dreaming simply will not support the claims of Freud - or of Joseph - to uncovering the 'true' meaning behind the disconnected narratives and bizarre imagery characteristic of REM dreams. It does not follow, however, that cognitive neuroscience has nothing of moment to say about the relation of dreaming to such topics as creativity, imagination or meaningfulness. Rather, 21st-century developments in dream research have elicited surprising new 
ways to approach such connections. I will turn now to consider recent work by Hobson's colleague Stickgold, a research psychiatrist specializing in the cognitive neuroscience of dreaming, that could hardly be termed reductive, save in the sense that Stickgold (in common with virtually all prominent brain researchers today) does assume the fundamental identity of mind and brain.

Pursuing interconnections among 'sleep, memory, dreams, meaning, and literature' (91), Stickgold provides the outlines of a scientific and broadly humanistic approach to dreaming, imagination and what neuroscientists term the brain's 'default mode' that considers a broad range of human imaginative activity, beginning with the wildly imaginative creativity experienced in dreams. For Stickgold, dreaming and other imaginative activities involve nothing less than the 'construction of meaning', a fundamental human activity involving such processes as forming 'associations, relationships, regularities, and rules' and constantly reordering both the remembered 'context of an individual's life to date' and the 'imaginal space' of his or her personal future (76-77). These meaning-making processes can take place both consciously and unconsciously and can proceed in a 'bottom-up' manner - building meaning up from detached images, experiences, ideas - or coalesce in a 'top-down' manner instead (89). According to Stickgold, the bottom-up mode is typified by dreams, the top-down mode by literature.

Indeed, for Stickgold dreams, which he reasonably assumes preceded even simple oral narratives in human mental and cultural evolution, constitute our true 'ur-literature' (88). Both dreaming and imaginative literature involve 'narrative, emotionality, bizarreness, sudden shifts in time and place, metaphor, and meaning' (88). And REM dreaming recruits many of the same brain areas as well as performing some of the key functions of the brain's default mode: a set of cognitive processes active when the brain-mind is not otherwise engaged, including episodic memory, prospective thinking about the future, 'theory of mind' or thinking about other people's mental states and daydreaming or wandering thoughts (90). All this leads Stickgold to a tantalizing conclusion: 'a major function of the brain is not all that different from the function of literature' (90). Stickgold's dream research exemplifies how cognitive neuroscience has circuitously returned to a notion of imagination that would have been familiar to the writers of high Romanticism, one that credits imagining with such fundamental aims as meaning-making, pattern construction, novel discrimination of resemblances and 'similes', intuition and creative invention $(76,81)$.

According to Stickgold, dreams provide a window into the workings of the brain-mind as it engages in a bottom-up process of meaning construction with little or nothing in the way of executive control. REM sleep 'represents a brain state in which novel and unexpected associations are more readily identified, enhancing creativity, the discovery of insight, and the construction of meaning' (87). This 'enhanced associative activity' is facilitated by the unique neurochemistry of REM dreaming, characterized by high levels of acetylcholine and low levels of norepinephrine and serotonin, greatly reducing cognitive accuracy and reliability while increasing the forming of the sort of loose associations that may well subtend insight and creativity (80-81). In terms of the activation of local- 
ized brain areas, those linked to reasoning and executive function barely register, while emotion areas such as the limbic system show high levels of activity.

The larger pattern of neural activation also overlaps with brain areas that neuroimaging studies have identified as constituting the brain's default network (Buckner, Andrews-Hanna and Schacter; Spreng, Mar and Kim; Richardson, 'Defaulting' 672, 685-689). This, Stickgold argues, helps us understand the narrative construction of dreams, since narrative forms a common thread among various cognitive activities implicated in the brain's default mode, notably including episodic memory or 'recall of autobiographical memories', theory of mind or 'divining the thoughts and intents of others' and prospection, 'imagining future worlds and scenarios'. In the default mode, Stickgold continues, the brain's 'greater purpose', like that of literature, is 'both to create a personal understanding of the world in which we live and to expand its boundaries' - to give meaning to experience encoded and stored as information and to construct new orderings and possibilities (90-91). These functions may be seen writ large in the activity of the 'dreaming brain' (91).

The connections posed here by Stickgold between dreaming, meaning making, literature and various 'default' functions had been previously explored, though in markedly different ways, during the Romantic era: a time of intense and in many ways unprecedented interest in dreaming and other mental phenomena associated with unconscious or spontaneous brain activity. An early 'default mode' approach to dreaming can in fact be traced in two celebrated and notoriously complex dreams represented in the poetry of Shelley (the poet's dream of the 'veiléd maid' in Alastor [Shelley 73-75]) and Keats (Madeline's dream of Porphyro in 'The Eve of St. Agnes' [Keats 312-315]). Both Keats and Shelley, as is now well known, took a pronounced interest in their era's pioneering brain science, which both established the ground for and resonates in remarkable ways with the cognitive neuroscience of our own time (Richardson, British Romanticism 114-150; Ruston 74-101).

To begin with, each of the invented dreams in question draws on images stored in memory in the process of envisioning a personal future - precisely the relation that neuroscientific studies of the 'default system' pose between episodic memory and 'prospective thinking' or, more colloquially, 'imagining the future' (Schacter, Rose and Buckner). The poet protagonist of Alastor, having glimpsed but consciously slighted a love-struck 'Arab maiden' not two dozen lines earlier in the poem, now dreams of a similarly dark-haired, exotic 'veiléd maid' who embodies 'hopes that never yet / Had flushed his cheek'. Madeline, for her part, goes to sleep anticipating (following traditional ritual practices) 'visions of delight', specifically (according to a variant text) of 'her future lord'; she fills in these visions with remembered images of her forbidden lover, Porphyro. Both dreams also feature another key function of the brain's default mode, 'theory of mind' (or 'mindreading') activities: Madeline is attempting to determine magically the marital intentions of her beloved, while the Alastor poet extrapolates an entire character from the amorous looks, seductive tones, flushing skin and revealing gestures of his dream girl. Each dream, in other words, centrally involves personal 
meaning-making, with Madeline literally putting a face on her deepest and most secret hopes, and the poet-hero of Alastor embodying the poetic practices, the political hopes and the thoughts 'most dear to him' in the form of an idealized female counterpart.

In both poems, the psychological status of the represented dream proves difficult to pin down with any great precision: is it a dream proper, a reverie or a visionary experience? Here the literary works notably depart from neuroscientific paradigms, muddying the very distinctions that science thrives by - much as dreaming, waking and reverie bleed into one another in Le Rêve de d'Alembert. Alastor seems initially to present a straightforward case of nocturnal dreaming: 'He dreamed a veiléd maid / Sate near him'. Yet the dream is introduced as a visionary experience - 'a vision on his sleep there came' - suggesting that some internal or even external agency has produced a vision marked by greater coherence and memorability than dreaming would ordinarily produce. ('The spirit of sweet human love has sent / A vision to the sleep of him who spurned / Her choicest gifts') And although the dream or vision enters 'on his sleep', at its conclusion the poet seems to fall back to sleep at its anticlimactic climax: 'Now blackness veiled his dizzy eyes ... sleep ... rolled back its impulse on his vacant brain'. The reader is left with all too many intriguing questions: does the 'spirit of sweet human love' represent the poet's deep, inarticulate and repressed passions or a form of supernatural agency or both? And has he been fully asleep, experiencing what would now be called REM dreaming, or lulled into a receptive state of waking reverie? Or does Shelley, like Hobson, Stickgold and other 21st-century dream researchers, understand nocturnal dreaming as a type of conscious experience (Hobson, Pace-Schott and Stickgold)?

Determining the status of Madeline's dream in 'The Eve of St. Agnes' proves if anything more perplexing and can be seen as a crux, perhaps an unresolvable one, for literary interpretation of the poem, at least in its published form. ${ }^{2}$ Some elements are clear: Madeline has fallen into an 'azure-lidded sleep', primed to dream of her future beloved and duly dreaming of Porphyro. That same Porphyro has cleverly, or treacherously, take your pick, managed to ensconce himself in Madeline's chamber and attempts to wake her up. He fails - her dream proves 'Impossible to melt' - and then Porphyro himself falls into a profound, dreamlike reverie, 'entoil'd in woofed phantasies'. When he comes to, he tries singing to Madeline, which finally has an effect: 'she panted quick - and suddenly / Her blue affrayéd eyes wide open shone'. And then the poem continues, teasingly: 'Her eyes were open, but she still beheld, / Now wide awake, the vision of her sleep'. Of course, since she was just dreaming of Porphyro and is now looking into his face, the dream may simply have ended and a waking experience of Porphyro taken its place. Yet the poem suggests, with such details as 'she look'd so dreamingly', that Madeline, though awake, remains in a dreamlike state. Moreover, the dream itself, even before she wakes, has incorporated Porphyro's actual presence and movements: 'even now / Thy voice was at sweet tremble at mine ear'. The lines between dreaming and sense perception, sleeping and waking, virtual and real image grow increasingly blurry, suggesting that Keats, like Diderot 
and Polidori, sees dreaming through the lens of 'somnambulism' as it was then understood.

The poem even broaches the possibility of sexsomnia, as Porphyro, now thoroughly aroused, somehow begins to participate in Madeline's 'dream': 'Into her dream he melted'. Again, the reader is left with unresolvable questions: does this line imply that Madeline has been dreaming all along? Or that 'dream' has moved from a literal to a metaphoric sense? Or, perhaps, that nocturnal dreaming has shaded imperceptibly into daydreaming, a half-conscious erotic reverie? In any case, Porphyro feels required to say, at the end of their dreamy, passionate encounter, 'This is no dream, my bride, my Madeline'. A statement that Madeline by no means takes as obvious: 'No dream, alas! alas! and woe is mine!'. If one takes this to mean that Madeline, at least, has up to then remained in or (alternatively) subsided back into a dream state, then sexsomnia, at least on her part, becomes a tempting resolution for the crux. On the other hand, if Madeline has more than half woken up, does she willingly engage in an erotic encounter under cover of somnambulism, or, more than half asleep, has she been a victim (as students sometimes assume) of what would now be called 'date rape' (Marcus 375)?

Notice how both dream passages, in Shelley as well as in Keats, end woefully: the poet in Alastor also cries, or the narrator cries out for him, 'Alas! Alas!'. In each case a process including (but perhaps not coterminous with) dreaming has drawn on memories to image forth a possible future, giving form to intimate hopes and desires, and yet produced a profound dissatisfaction with the quotidian world of waking experience. Madeline cannot reconcile Porphyro's actual appearance with the 'looks immortal' beheld in her dream: 'How chang'd thou art! how pallid, chill, and drear!'. The Alastor poet has no present image to compare with the exotic maid's imagined one: she has no existence outside his dream world, evacuating the everyday world of all meaning: 'His wan eyes / Gaze on the empty scene as vacantly / As ocean's moon looks on the moon in heaven'. This world of pale, watery reflections proves painfully inadequate to the visionary world of dream and reverie. Both poems imply that the imaginative construction of meaning can backfire, and end by draining meaning from ordinary life.

Finally, both dreams are highly allusive and self-consciously literary, suggesting both poets' awareness that dreaming, seemingly a private activity, in fact participates in public discourses; that, like other narrative acts, dreaming must draw on a collective storehouse of images and on shared cultural codes. At the individual human level, meaning and meaningfulness must be understood, as Stickgold stresses, as 'personal': each mind-brain (or, if one prefers, each subject) uniquely situated in time and space, situated, moreover, in a unique body, and with its own distinctive array of memories and other information traces, will develop its own idiosyncratic set of meanings. And yet these meanings interact pervasively with and are largely constructed from larger social networks of meaning - including those complex networks we gesture toward with terms like culture, ideology, habitus and background.

Nothing could be more personal to Madeline than her romantic hopes and erotic feelings for Porphyro, and yet these feelings are worked out along the lines 
of the cultural expectations and social scripts to which she is exposed. It is no accident that this romance begins in an institutional setting, a Catholic church. The St. Agnes' Eve ritual that Madeline must follow in order to dream of her husband-to-be is one performed by countless other Madelines before, since, and no doubt on that same chilly evening. The fifth stanza of the poem, heralding the entrance of Madeline and the rest of the local gentry into the church, could hardly be more emphatic on how each developing mind (Keats actually says 'brain') gets 'stuff'd' with established cultural scripts (299):

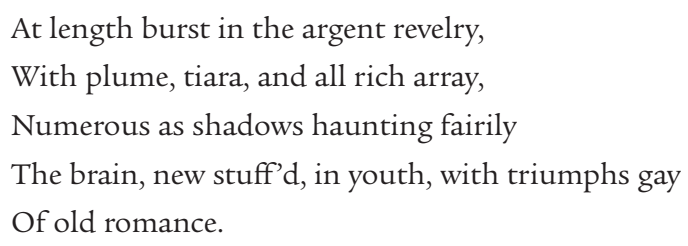

Porphyro too acts out a script from 'old romance', though just what script precisely remains under debate. Porphyro himself calls it 'La belle dame sans mercy' (the song he sings to dreaming Madeline); others see Porphyro less as a lovestruck, despairing knight than a predatory figure related to the conventional demon lover or even to the vampire (Stillinger, 'The Hoodwinking of Madeline' 539-540; Stillinger, Reading 46-47). Either way, Porphyro hijacks the St. Agnes' Eve ritual not to disrupt it but to insert himself into the 'future lord' slot, and his singing of an 'ancient ditty' to a sleeping Madeline may well reflect his attempt to channel her dreaming into a stereotypical romantic narrative of his own choosing.

The ill-fated dream date in Alastor rehearses a basic scenario endemic to Orientalist writing of the long 18 th century: the adventurous male European finding his ultimate erotic partner in an exotic, idealized, Oriental woman. (This scenario is sometimes termed, in cultural studies shorthand, 'the exotic is the erotic', a formula that goes back as far as Praz [207].) More specifically, Shelley borrows heavily here from an earlier Romantic-era narrative describing just such a culturally fraught and erotically overcharged encounter: Sydney Owenson's Orientalist novel The Missionary. Although Shelley's Orientalized singer departs in certain important ways from Owenson's Luxima - the veiléd maid, for example, chants of 'divine liberty' while Luxima devotes her songs to 'Camdeo, the god of mystic love' (99) - Shelley consciously and overtly models his exotic poetess on Owenson's (then) celebrated Hindu vestal (Judson). Most saliently, the Alastor poet encounters his visionary maid in the 'vale of Cashmire', Luxima's home in The Missionary and a setting already made famous for its lushness and pristine 'Indian' character by the great Orientalist Sir William Jones. Like Luxima, Shelley's visionary maid ineffectively screens a 'lovely and luxuriant' person behind a diaphanous veil, sings inspired verses in a hauntingly beautiful voice, combines 'purity' with an irresistibly erotic manner, sports 'long dark hair' that 'floated in the wind' and reveals her passionate nature in a fit of 'soft and unrepressed transport' (Owenson 97, 109, 147-148; cf. Alastor lines 163, 178-180). Readers of The Missionary cannot 
miss the veiléd maid's pronounced resemblance to Luxima (who also appears 'like the tender vision which descends upon Passion's dream' [162]) and Shelley does not want them to. The Alastor poet's dream represents at one and the same time 'Thoughts the most dear to him' and a stock cultural script already well established in British Orientalist literature.

Each dream participates in larger-scale ideological discourses, particularly in relation to gender and empire. In rehearsing the stock Orientalist fantasy scenario of an exceptional European male overcoming the resistance ('she drew back awhile') of an exotic beauty, Alastor implicitly endorses the 'Western=male=dominant / Asian=female=subordinate' equation endemic to Orientalist discourse. This equation is unabashedly spelled out in Shelley's primary source for this encounter, the meeting of Hilarion and Luxima in Owenson's Missionary: 'they stood finely opposed, the noblest specimens of the human species, as it appears in the most opposite regions of the earth: she, like the East, lovely and luxuriant; he, like the West, lofty and commanding'. Owenson only intensifies this fundamental contrast and the power differential it implies as the passage goes on: 'she, looking like a creature formed to feel and to submit; he, like a being created to resist and to command' (109). Shelley seeks to qualify this opposition by making the veiled maid both poetically inspired and politically informed, and indeed Owenson's narrative sometimes puts into question the same contrast it so blatantly poses, yet in each case the basic scenario confirms an deeply unequal social relation between European and Oriental, male and female.

'The Eve of St. Agnes', in its own uneasy manner, gives literary form to key aspects of the bourgeois domestic ideology of the era: Madeline is associated with domestic interiors, with passive positions (supine in bed) and with romantic fantasy, while Porphyro has the freedom to come and go (even on enemy territory), takes active roles, and proves capable of manipulating romance patterns to his own (however dubious) ends. The St. Agnes' Eve ritual in itself implies that the chief business of bourgeois women like Madeline must be to marry; the dream reveals not whether to marry, but whom. More than that, the very prophetic character of the dream implies a lack of agency: Madeline will not choose Porphyro, but hopes to be chosen by him. Porphyro's singing of 'La Belle Dame Sans Merci' might seem to subtly undermine this formula, implying that it is the woman who chooses, who decides whether to pity her beseeching lover or not, yet (especially in context) the allusion to courtly romance traditions does not so much overturn the domestic ideology of Keats's time as obscure or disavow its ineluctable force.

\section{Conclusion}

Are dreams ever to be considered 'private', do they ever reflect solely the preoccupation and movements of an individual mind? In an important consideration of Le Rêve de d'Alembert in the broader context of Diderot's 'dynamic materialism', Wilda Anderson suggests that d'Alembert's dream itself may be viewed as a kind of 'polyp', as much an aggregate as the fragmented self that dreams it and the 
disintegral subject that receives it $(1,65)$. The dream incorporates ideas suggested by the fictional Diderot in the preliminary dialogue no less than the sleeping d'Alembert's reactions and elaborations, these in turn shaped by the contributions of Mlle. de L'Espinasse (who writes out the first part of the dream and whose presence clearly shapes it) and Bordeu, who at times fills out the lacunae in Mlle.'s transcription and whose own suggestions and elaborations become in turn drawn into d'Alembert's somniloquy. The participants in the dialogue, in Anderson's reading, resemble the 'bee swarm' in the dialogue itself: 'Our interlocutors ... have not lost their own identities, but they have managed to construct a larger identity that includes them all-all four of them' (66). And, as we have noticed, this exemplary dialogical dream also incorporates any number of contemporary physiological and ideological discourses, sometimes (as in the borrowing of that same bee swarm image from a prior text of Bordeu's) in a manifestly knowing manner. Like the dreams represented by Keats and Shelley, d'Alembert's dream includes intertextual as well as dialogical and ideological dimensions that extend well beyond the dreamer's individual subjectivity, or rather, expose the corporate and interdependent nature of all human subjectivity.

Over the course of this essay, I have made two complementary arguments, reflecting the dual focus informing the practice of cognitive historicism. In relation to historical literary interpretation, I hope to have shown that informed attention to cognitive neuroscience in the present can elicit unnoticed or undervalued aspects of past literary artifacts and discourses. Lessons from the cognitive neuroscience of dreaming, for example, can help us appreciate the ideological challenge posed by Enlightenment and Romantic accounts and representations both of dreams and of the very activity of dreaming. The work of Stickgold in particular can help us to new appreciations of old connections between dreaming and literary creativity, as well as to views of dreaming in relation to a whole suite of activities - including remembering the past, imagining a possible future and speculating on the emotions and intentions of others - newly grouped together as aspects of the brain's default system.

Cognitive historicist literary investigation can, in turn, reveal some of the biases and potential blind spots of scientific research agendas. The emphasis placed by current scientific dream researchers on REM dreaming, for example, may downplay some of the more unorthodox implications of the brain's activity during sleep. It seems notable that dream science should have 'discovered' sexsomnia only quite recently, although Diderot represented it over two centuries ago and it arguably features in one of Keats's best known poems. Sleep sex brings out quite graphically the disturbing (not to say titillating) aspects of a brain unshackled from conscious supervision and cultural norms, troubling notions of agency and volition, in an especially salient manner. Earlier theories and representations of dreaming also serve to remind us that at least some of the lines drawn by scientific investigators - say, between dreaming and reverie, or waking and sleeping consciousness, which in Diderot, Shelley and Keats seamlessly blend into one another - may ultimately prove overstated, however useful for the purposes of study design: statistical differences presented as hard categorical distinctions. 
Most importantly, the literary texts examined here remind us that dreams reveal ideological as well as emotional investments, construct personal meanings out of public discourses and confound any firm division between private and political. All three texts break down any sense of private ownership of a given dream, suggesting instead that dreams (at least invented, literary dreams) exhibit, like other discursive forms, dialogical features: in the corporate subjectivity informing 'd'Alembert's' dream, in the ways that Porphyro helps shape and even enters into Madeline's dream ('into her dream he melted'), and in the patent rehearsal of an earlier Orientalist text in the Alastor poet's dream of his veiled maid. Each dream also evokes pressing social and ideological issues: Diderot's materialist critique of a whole range of contemporary orthodoxies, Shelley's engagement with a highly gendered version of Orientalist discourse, Keats's underscoring, critical or not, of the domestic ideology recently challenged by Mary Wollstonecraft and other pioneering feminists. And yet all three of these fictional dreams harbors utopian tendencies as well, not least in the way they unleash erotic energies in defiance of social and literary notions of decorum. The dreamer never ceases to function as a political and ideological subject, even as discrete individual subjectivity itself is exposed as an ephemeral dream. 


\section{Literature}

Andersen, Monica L., Dalva Poyares, Rosana S. C. Alves, Robert Skomro and Sergio Tufik. 'Sexsomnia: Abnormal Sexual Behavior During Sleep'. Brain Research Reviews 56 (2007): 271-282.

Anderson, Wilda. Diderot's Dream. Baltimore: Johns Hopkins UP, 1990.

Buckner, Randy L., Jessica R. Andrews-Hanna and Daniel L. Schacter. 'The Brain's Default Network: Anatomy, Function, and Relevance to Disease'. Annals of the New York Academy of Sciences 1124 (2008): 1-38.

Cai, Denise J., Sarnoff A. Mednick, Elizabeth M. Harrison, Jennifer C. Kanaday and Sara C. Mednick. 'REM, Not Incubation, Improves Creativity by Priming Association Networks'. PNAS 106.25 (June 23, 2009): 10130-10134.

Coleridge, Samuel Taylor. The Notebooks of Samuel Taylor Coleridge. Ed. Kathleen Coburn. 5 vols. London: Routledge and Kegan Paul, 1957-2002.

Curran, Andrew. 'Monsters and the Self in the Rêve de d'Alembert. Eighteenth-Century Life 21.2 (1997): 48-69.

Diderot, Denis. D'Alembert's Dream. In Rameau's Nephew and Other Works. Ed. Jacques Barzun and Ralph H. Bowen. Garden City, NY: Doubleday, 1956. 95-182.

Diderot, Denis. Le Rêve de d'Alembert. In Oeuvres Philosophiques. Ed. Michel Delon and Barbara Negroni. Paris: Gallimard, 2010. 344-409.

Hartley, David. Observations on Man. 2 vols. 1791. Poole, England: Woodstock, 1998.

Hazlitt, William. The Complete Works of William Hazlitt. Ed. P. P. Howe. 21 vols. London: Dent, 19301934

Hobson, J. Allan. Dreaming: A Very Short Introduction. Oxford: Oxford University Press, 2005.

Hobson, Edward F. Pace-Schott and Robert Stickgold. 'Consciousness: Its Vicissitudes in Waking and Sleep'. The New Cognitive Neurosciences. Ed. Michael S. Gazzaniga. 2nd ed. Cambridge, MA: MIT P, 2000. 1341-1354.

Judson, Barbara. 'Under the Influence: Owenson, Shelley, and the Religion of Dreams'. Modern Philology 104.2 (November 2006): 202-223.

Keats, John. The Poems of John Keats. Ed. Jack Stillinger. Cambridge: Harvard University Press, 1978.

Lavie, Peretz and J. Allan Hobson. 'Origin of Dreams: Anticipations of Modern Theories in the Philosophy and Physiology of the Eighteenth and Nineteenth Centuries'. Psychological Bulletin 100.2 (1986): 229-240.

Marcus, Steven. 'Soft Totalitarianism'. A Partisan Century: Political Writings from Partisan Review. Ed. Edith Kurzweil. New York: Columbia UP, 1996. 370-376.

[Ménuret de Chambaud, Jean-Joseph]. 'SOMNAMBULE, \& SOMNAMBULISME'. Encyclopédie, ou dictionnaire raisonné des sciences, des arts et des métiers, etc. Ed. Denis Diderot and Jean le Rond D’Alembert. Vol. 15. University of Chicago: ARTFL Encyclopédie Project (Spring 2011 Edition), Robert Morrissey (ed.), http://encyclopedie.uchicago.edu/. 340-342.

Moravia, Sergio. 'From Homme Machine to Homme Sensible: Changing Eighteenth-Century Models of Man's Image'. Journal of the History of Ideas 39.1 (Jan.-March 1978): 45-60.

Owenson, Sidney (Lady Morgan). The Missionary: An Indian Tale. Ed. Julia M. Wright. Peterborough, ONT: Broadview, 2002.

Polidori, John William. 'An English Translation of John William Polidori's (1815) Medical Dissertation on Oneirodynia (Somnambulism)'. Trans. and with notes by David Petrain. European Romantic Review 21:6 (2010): 775-788. 
Praz, Mario. The Romantic Agony. Trans. Angus Davidson. 2nd ed. London: Oxford University Press, 1970.

Richardson, Alan. British Romanticism and the Science of the Mind. Cambridge: Cambridge University Press, 2001.

Richardson, Alan. 'Coleridge and the Dream of an Embodied Mind'. Romanticism 5.1 (1999): 1-25.

Richardson, Alan. 'Defaulting to Fiction: Neuroscience Rediscovers the Romantic Imagination'. Poetics Today 32:4 (Winter, 2011): 663-692.

Richardson, Alan. The Neural Sublime: Cognitive Theories and Romantic Texts. Baltimore: Johns Hopkins University Press, 2010.

Ruston, Sharon. Shelley and Vitality. Houndsmills: Palgrave Macmillan, 2005.

Schacter, Daniel L., Donna Rose Addis and Randy L. Buckner. 'Remembering the Past to Imagine the Future: The Prospective Brain'. Nature Reviews: Neuroscience 8 (September 2007): 657-661.

Schwartz, Delmore. 'In Dreams Begin Responsibilities'. 1937. In Dreams Begin Responsibilities and Other Stories. Ed. James Atlas. New York: New Directions, 1978. 1-9.

Shelley, Percy Bysshe. Shelley's Poetry and Prose. Ed. Donald H. Reiman and Sharon B. Powers. New York: Norton, 1977.

Spolsky, Ellen. 'Cognitive Literary Historicism: A Response to Adler and Gross'. Poetics Today 24.2 (2003): 161-183

Spreng, R. Nathan, Raymond A. Mar and Alice S. N. Kim. 'The Common Neural Basis of Autobiographical Memory, Prospection, Navigation, Theory of Mind, and the Default Mode: A Quantitative Meta-analysis'. Journal of Cognitive Neuroscience 21.3 (2008): 489-510.

Stickgold, Robert. 'Memory in Sleep and Dreams: The Construction of Meaning'. The Memory Process: Neuroscientific and Humanistic Perspectives. Ed. Suzanne Nalbantian, Paul Matthews and James L. McLelland. Cambridge, MA: MIT Press, 2011. 73-95.

Stickgold, Laurie Scott, Cynthia Rittenhouse and J. Allan Hobson. 'Sleep-Induced Changes in Associative Memory'. Journal of Cognitive Neuroscience 11.2 (1999): 182-193.

Stiles, Anne, Stanley Finger and John Bulevich. 'Somnambulism and Trance States in the Works of John William Polidori, Author of The Vampyre'. European Romantic Review 21:6 (2010): 789-807.

Stillinger, Jack. 'The Hoodwinking of Madeline: Scepticism in The Eve of St. Agnes'. Studies in Philology 58.3 (July 1961): 533-555.

Williams, Elizabeth A. The Physical and the Moral: Anthropology, Physiology, and Philosophical Medicine in France, 1750-1850. Cambridge: Cambridge University Press, 1994.

Yeats, William Butler. The Complete Poems of W. B. Yeats. New York: MacMillan, 1956. 


\section{Notes}

1 Quotations from Diderot are given first in English, from the translation in Barzun and Bowen's edition, and then in the French original, following the 2010 Gallimard edition by Michel Delon. Where two page numbers are given separated by a slash, the second refers to the French edition.

2 Keats produced a revision of lines 314-322, which his publishers refused to accept, that included the phrase 'Still, still she dreams' (Stillinger, 1999 26-27). For Stillinger, this version 'makes clearer that Madeline is still dreaming' (Stillinger, 'The Hoodwinking of Madeline' 545), but what then do we make of the phrase, in the previous stanza, 'now wide awake'? To me, the passage remains highly ambiguous. 